Arq. Bras. Med. Vet. Zootec., v.62, n.4, p.778-783, 2010

\title{
In vitro evaluation of Clostridium septicum alpha toxoid
}

[Avaliação in vitro de toxoide alfa de Clostridium septicum]

\author{
F.M. Salvarani ${ }^{1}$, Z.I.P. Lobato $^{1}$, R.A. Assis ${ }^{2}$, C.G.R.D. Lima ${ }^{1}$, R.O.S. Silva ${ }^{1}$, P.S. Pires ${ }^{1}$, F.C.F. Lobato ${ }^{1 *}$ \\ ${ }^{1}$ Escola de Veterinária - UFMG - Belo Horizonte, MG \\ Av. Antonio Carlos, 6627 \\ 31270-901 - Belo Horizonte, MG \\ ${ }^{2}$ Lanagro-MG - MAPA - Pedro Leopoldo, MG
}

\begin{abstract}
Aiming to investigate in vitro alternatives, a test for neutralizing antibody detection using cell culture was developed. This test was more sensitive than previous animal models, allowing for detection of substantially lower alpha toxin and anti-alpha toxin titers. Titers observed during in vivo and in vitro seroneutralization had a correlation of $99.12 \%$, indicating that cell culture is a viable alternative in the evaluation of vaccine potency, screening of vaccinal seeds, and Clostridium septicum alpha toxin titration.
\end{abstract}

Keywords: seroneutralization, mouse, guinea pig, cell culture, vaccine

\section{RESUMO}

Padronizou-se um teste para detecção de anticorpos neutralizantes in vitro, em cultura de células. $O$ modelo in vitro mostrou-se mais sensível que os testes com animais, permitindo a detecção de títulos de toxina e antitoxina alfa mais baixos. Os títulos observados na soroneutralização in vivo $e$ in vitro, apresentaram correlação de 99,12\%, demonstrando ser a cultura de células uma alternativa viável na avaliação da potência de vacinas, triagem de sementes vacinais e titulação de toxina alfa de Clostridium septicum.

Palavras-chave: soroneutralização, camundongo, cobaio, cultura de células, vacina

\section{INTRODUCTION}

Among the clostridial species with veterinary importance, Clostridium septicum is highlighted as the ethiological agent of gas gangrene or malignant edema, a pathology that affects mainly ruminants and results in considerable losses to the ruminant industry. The pathogenesis of this disease involves the penetration and multiplication of the microorganism, which leads to toxin production and, consequently, the nosological picture. C. septicum produces four main toxins termed alpha, beta, gamma, and delta. Alpha toxin is the main protein involved in the pathological properties of $C$. septicum due to its biological activities (Popoff and Bouvet, 2009).

Recebido em 5 de outubro de 2009

Aceito em 30 de julho de 2010

*Autor para correspondência (corresponding author)

E-mail: flobato@vet.ufmg.br
The economic losses caused by this disease are hard to evaluate due to the lack of available data. However, losses are estimated to be significant because of the high lethality associated with this condition (Baldassi et al., 1985). From January 1990 to December 2007, 14,895 cases of myonecrosis (black leg and gas gangrene) were registered, according to the Animal Health Office at the Ministry of Agriculture, Livestock, and Food Supply in the State of Minas Gerais, Brazil. This group of diseases accounted for one of the highest mortality rates among infectious diseases of cattle (Assis et al., 2008).

The eradication of $C$. septicum is virtually impossible due to the ubiquity of this pathogenic agent, and its control is based on preventive 
management measures and systematic vaccination of the herd (Assis et al., 2010).

Approximately 148 million doses of clostridial vaccines are produced in Brazil each year, demonstrating the widespread use of these immunogens. The standard technique to evaluate clostridial vaccine potency is seroneutralization (SN) in mice (Brasil, 1997). The dermonecrotic test (DN) in guinea pigs is an alternative tool in antibody titration that significantly reduces the number of animals used (Sakurai and Kobayashi, 1995).

The use of animals in research and diagnosis has generated countless ethical discussions by humanitarian groups and researchers with the aim of promoting animal welfare. Therefore, there is a need to develop and standardize low cost in vitro methodologies that present quick results with good sensitivity and specificity. In this research field, the use of cell lines has become a viable and efficient option to replace animal models (Metz et al., 2002).

The objectives of this work were to titrate $C$. septicum alpha toxin in VERO (African Green Kidney Monkey) cells and standardize an in vitro seroneutralization test to evaluate the potency of the alpha toxoid by comparison with the animal bioassay.

\section{MATERIAL AND METHODS}

A strain of C. septicum (ATCC 12464) from the American Type Culture Collection, USA, was used to produce the alpha toxin in a five liter capacity benchtop bioreactor (BioFlo 110 - New Brunswick Scientific Co - Warrington, UK). Toxin production was performed as described by Ballard et al. (1992).

A standard serum (NIBSC - London, UK) with $10 \mathrm{IU} / \mathrm{mL}$ of anti-alpha toxin antibodies was used for alpha toxin standardization. From a pool of rabbits immunized with the commercially available (as of 2007) clostridial vaccines containing $C$. septicum, 11 test sera were obtained for this study. For each vaccine, eight rabbits were subcutaneously inoculated with the lowest dose recommended by the manufacturer (British Pharmacopeia, 1998). The vaccine was substituted with $0.85 \%$ saline for the negative control group. C. septicum standard alpha toxoid ${ }^{2}$ was used in the control group. The use of animals in this study was approved by the Ethics Committee for Animal Experimentation (CETEA-UFMG, nº 51/2007).

The VERO continuous cell line was cultivated in minimum essential medium (MEM - Gibco Laboratories - Massachusetts, USA) supplemented with 5\% fetal bovine serum (Difco Laboratories - New Jersey, USA), 40,000IU/mL of penicillin and $20,000 \mathrm{IU} / \mathrm{ml}$ of streptomycin (Hang'Ombe et al., 2004).

Two-fold serial dilutions were made in $1 \%$ peptonated saline. From each dilution, $0.2 \mathrm{~mL}$ was endovenously inoculated in five mice and intradermally in one guinea pig. Mice were observed over 72 hours and the guinea pig was observed for 48 hours. The minimal lethal dose per $\mathrm{mL}$ (MLD/mL) was determined according to the British Pharmacopeia (1998). The dermonecrotic effect per $\mathrm{mL}$ (DNE/mL) was determined according to Sakurai and Kobayashi (1995).

Serial two-fold dilutions of the toxin were made in a 96-well plate (Sarstedt - North Carolina, USA) with $50 \mu \mathrm{L} /$ well and four repetitions. Later, another $50 \mu \mathrm{L}$ of $\mathrm{MEM}$ and $50 \mu \mathrm{L}$ of cellular suspension containing $2.5 \times 10^{4}$ cells were added for a total volume of $150 \mu \mathrm{L}$ per well. The positive control contained $100 \mu \mathrm{L}$ of the toxin plus $50 \mu \mathrm{L}$ of cells, while the negative control included $100 \mu \mathrm{L}$ of MEM and $50 \mu \mathrm{L}$ of cells. The plate was incubated at $37^{\circ} \mathrm{C}$ in a humid chamber (Sheldon Manufacturin Inc - Oregon, USA) with a controlled atmosphere $\left(5 \% \mathrm{CO}_{2}\right.$ and $\left.95 \% \mathrm{O}_{2}\right)$ for 48 hours. The supernatant was removed after this period. Staining was done with $100 \mu \mathrm{L}$ of crystal violet solution $(0.1 \%$ in alcohol) to observe the cytopathic effect (CPE) (Souza Júnior et al., 2010). CPE was considered to be the destruction of $100 \%$ of the cellular monolayer.

Alpha toxin was standardized in mice and guinea pig at the test level L+/5. The methodologies used for standardization of the alpha toxin in both systems were undertaken according to the British Pharmacopeia (1998) and Knight et al. (1990a), respectively. Alpha toxin was standardized in the VERO cell line at the test level L+/25 (Knight et al, 1990a). The methodology used to standardize the alpha toxin 
in the cell model is described in Souza Júnior et al. (2010).

Two-fold serial dilutions of the test sera were made in $1 \%$ peptonated saline and homogenized with the same volume of toxin previously standardized at the test level $\mathrm{L}+/ 5$ in the mice and guinea pig. This mix was then kept at $37^{\circ} \mathrm{C}$ for 30 minutes. Subsequent inoculation followed as previously described. Retrotitration with standard anti-toxin was used to measure the standardization of the toxin in both systems (Lobato et al., 2008).

Two-fold serial dilutions of the test sera into MEM were made into the 96-well plate (Sarstedt), with four repetitions for each serum dilution and a total volume of $50 \mu \mathrm{L}$ in each well. Another $50 \mu \mathrm{L}$ was then added to each well containing alpha toxin standardized at the test level L+/25. The plate was manually homogenized for 30 seconds and incubated at $37^{\circ} \mathrm{C}$ for one hour in a humid chamber (Sheldon) with a controlled atmosphere. After this period, $50 \mu \mathrm{L}$ of a cellular suspension with $2.5 \times 10^{4}$ cells were added. The plate was then reincubated for another 48 hours. Positive control wells contained $50 \mu \mathrm{L}$ of standardized toxin, $50 \mu \mathrm{L}$ of MEM, and $50 \mu \mathrm{L}$ of cells. Negative control wells had $100 \mu \mathrm{L}$ of MEM and $50 \mu \mathrm{L}$ of cells. Serum control wells had $50 \mu 1$ of the test serum, $50 \mu \mathrm{L}$ of MEM, and $50 \mu \mathrm{L}$ of cells. The plate was read as previously described. Retrotitration with standard anti-toxin was used to check the standardization of the toxin (Souza Júnior et al., 2010).

This study was designed as random blocks with 11 repetitions for each experimental group. To analyze the results, a parametrical correlation using Pearson's correlation was utilized (Sampaio, 1998).

\section{RESULTS AND DISCUSSION}

The results of the titration of the $C$. septicum alpha toxin in the three experimental models (mouse, guinea pig, and cell models) are shown in Table 1.

Table 1. Clostridium septicum alpha toxin titration in animals and VERO cells

\begin{tabular}{cc}
\hline $\begin{array}{c}\text { Experimental } \\
\text { model }\end{array}$ & Titer \\
\hline Mouse & $2,290 \mathrm{MLD} / \mathrm{mL}$ \\
Guinea pig & $7,680 \mathrm{DNE} / \mathrm{mL}$ \\
VERO cells & $2,621,440 \mathrm{CPE} / \mathrm{mL}$ \\
\hline
\end{tabular}

MLD: minimal lethal dose; DNE: dermonecrotic effect; CPE: cytopathic effect.

The obtained titers demonstrate the higher sensitivity of the cell culture to $C$. septicum alpha toxin due to the detection of concentrations that are 1,140 times lower than those detected by the mouse model and 340 times lower than the guinea pig model. These results show that the titration of the alpha toxin in VERO cells may be used to select $C$. septicum vaccine seeds instead of the bioassay. This reduction in the use of animals for $C$. septicum screening addresses the bioethical issues surrounding this evaluation.

Toxin standardization by standard homologous anti-toxin at the test levels determined is needed to use this toxin in the seroneutralization tests. The results of the titers obtained in the standardization of $C$. septicum alpha toxin in mice, guinea pigs, and VERO cells are shown in Table 2.

Table 2. Standardization of $C$. septicum alpha toxin in mouse $(\mathrm{L}+/ 5)$, guinea pig $(\mathrm{L}+/ 5)$, and VERO cells culture $(\mathrm{L}+/ 25)$ by standard homologous anti toxin

\begin{tabular}{lccc} 
& Mouse & Guinea pig & VERO cells culture \\
\hline $\begin{array}{l}\text { Titer obtained at the recommended test } \\
\text { level }\end{array}$ & $400 \mathrm{~L}+/ 5 / \mathrm{mL}$ & $600 \mathrm{~L}+/ 5 / \mathrm{mL}$ & $5,120 \mathrm{~L}+/ 25 / \mathrm{mL}$ \\
$\begin{array}{l}\text { Volume administered in each } \\
\text { experimental model }\end{array}$ & $0.2 \mathrm{~mL}$ & $0.2 \mathrm{~mL}$ & $0.15 \mathrm{~mL}$ \\
$\begin{array}{l}\text { Equivalent units of the anti-toxin in the } \\
\text { volume above }\end{array}$ & $0.2 \mathrm{IU}$ & $0.2 \mathrm{IU}$ & $0.04 \mathrm{IU}$ \\
\hline
\end{tabular}

Titers found in the $C$. septicum alpha toxin standardization in mice $(400 \mathrm{~L}+/ 5 / \mathrm{mL})$, guinea pig $(600 \mathrm{~L}+/ 5 / \mathrm{mL})$, and cells $(5,120 \mathrm{~L}+/ 25 / \mathrm{mL})$ were higher than those found by Knight et al. (1990a) of $117 \mathrm{~L}+/ 5 / \mathrm{mL}, 158 \mathrm{~L}+/ 5 / \mathrm{mL}$, and $4,380 \mathrm{~L}+/ 25 / \mathrm{mL}$, respectively. This difference 
may be explained by the higher titer of toxin produced in this experiment. Furthermore, when these results are compared to data obtained by Knight et al. (1990b) in the standardization of $C$. perfringens type $\mathrm{D}$ epsilon toxin, in which the authors found $172 \mathrm{~L}+/ 10 / \mathrm{mL}$ in mice, $540 \mathrm{~L}+/ 25 / \mathrm{mL}$ in guinea pigs, and $1,600 \mathrm{~L}+/ 50 / \mathrm{mL}$ in Madin-Darby Canine Kidney cells, it is possible to observe that the cell culture was the most sensitive system.

Titrations of the test sera by in vivo and in vitro seroneutralization were made after standardization of the toxin. The titers of neutralizing antibodies against $C$. septicum alpha toxin in the three systems used are described in Table 3 .

Table 3. Titers of neutralizing antibodies against Clostridium septicum alpha toxin in pool sera from rabbits immunized with commercially available vaccines containing alpha toxoid by seroneutralization in mice, guinea pigs, and VERO cells

\begin{tabular}{cccc}
\hline Sera & \multicolumn{3}{c}{ Antibody titer (IU/mL) } \\
\cline { 2 - 4 } & Mouse & Guinea pig & VERO cells culture \\
\hline T1 & 2.0 & 2.0 & 1.6 \\
T2 & 6.9 & 6.9 & 6.4 \\
T3 & 5.7 & 5.7 & 6.4 \\
T4 & 5.7 & 5.7 & 6.4 \\
T5 & 2.0 & 2.0 & 1.6 \\
T6 & 2.0 & 2.0 & 1.6 \\
T7 & 4.0 & 4.0 & 3.2 \\
T8 & 4.0 & 2.0 & 3.2 \\
T9 & 2.0 & 11.5 & 1.6 \\
T10 (positive control) & 11.5 & - & 12.8 \\
T11 (negative control) & - & & - \\
\hline
\end{tabular}

Interpreting the data in Table 3 , the values obtained during seroneutralization in mouse and guinea pig are statistically the same by Student's $\mathrm{T}$ test $(\mathrm{P} \leq 0.05)$. The bioassays have a concordance of $1 \quad(\mathrm{P}<0.05)$ by Pearson's correlation (Figure 1), superior to the 0.95 found by Knight et al. (1990a). The calculated $R^{2}$ was 1 , which proves that antibody titers in these two systems are $100 \%$ correlated. These results indicate that the use of guinea pigs may be an another option to $C$. septicum tests in mice. This is a viable alternative for evaluation due to the fact that significantly less animals are required, since two vaccines can be tested in one guinea pig.

Furthermore, analysis of the vaccine potency test demonstrates that the results of $6.9 \mathrm{IU} / \mathrm{ml}$ in the bioassays and $6.4 \mathrm{IU} / \mathrm{ml}$ in VERO cells are statistically the same by the Student's T test $(\mathrm{P} \leq 0.05)$, indicating an association between the titers obtained in the different experimental models to the vaccines tested. By Pearson's correlation (Fig. 2), a concordance of 0.9912 $(\mathrm{P}<0.05)$ between titers in bioassay and VERO cells was found, a value higher than that 0.91 found by Knight et al. (1990a). Therefore, correlation between in vivo and in vitro models is significantly high. The calculated $\mathrm{R}^{2}$ equals 0.9824 , meaning that antibody titers in the tested models are $98.24 \%$ associated. Significant correlation of $92 \%$ was also reported by Knight et al. (1990b). The viability of substituting the animal bioassay by in vitro models is thus proved.

Cell culture presents a series of advantages over the animal bioassay in titration of antibodies against $C$. septicum alpha toxin, specifically the drastic reduction in the number of animals used, higher sensitivity of the test, smaller variation in the individual responses, and decrease in the amount of standard reagents. 


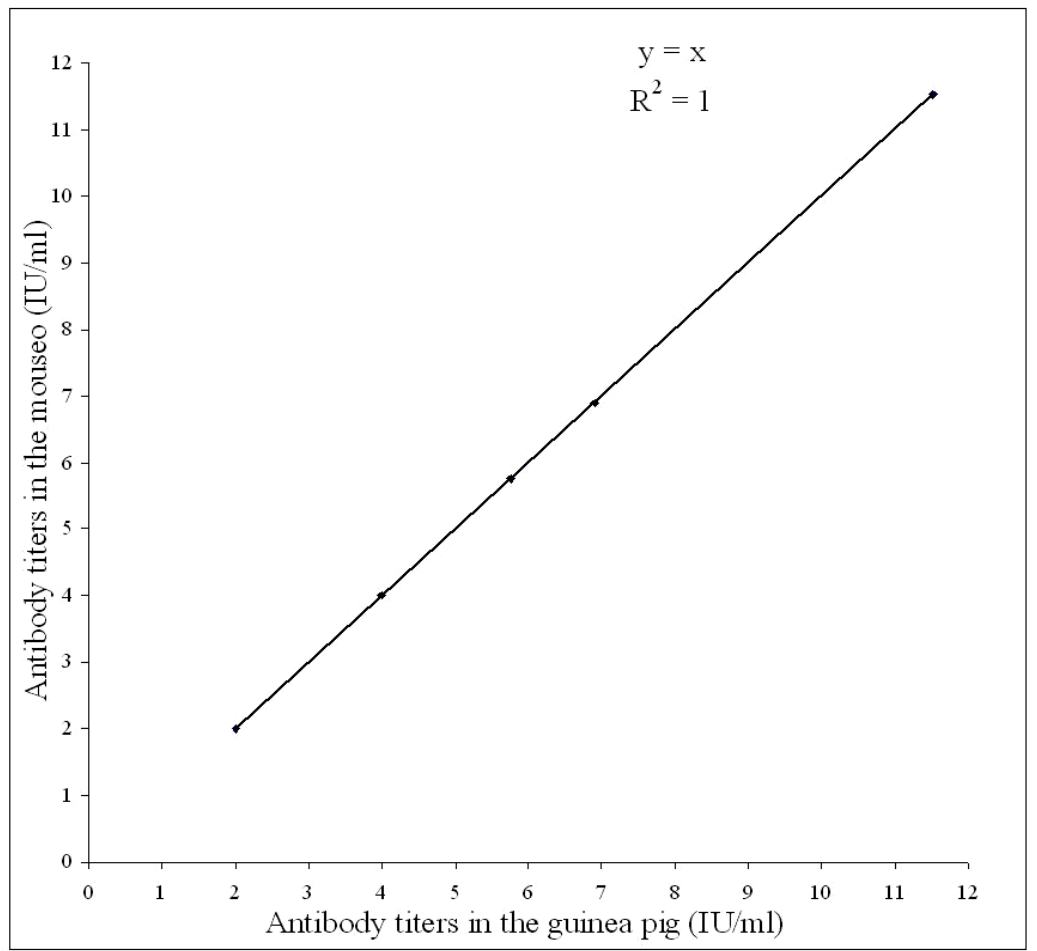

Figure 1: Pearson's correlation between titers of neutralizing antibodies against Clostridium septicum alpha toxin in rabbit sera obtained by seroneutralization in mouse and guinea pig, $\mathrm{R}^{2}=1$.

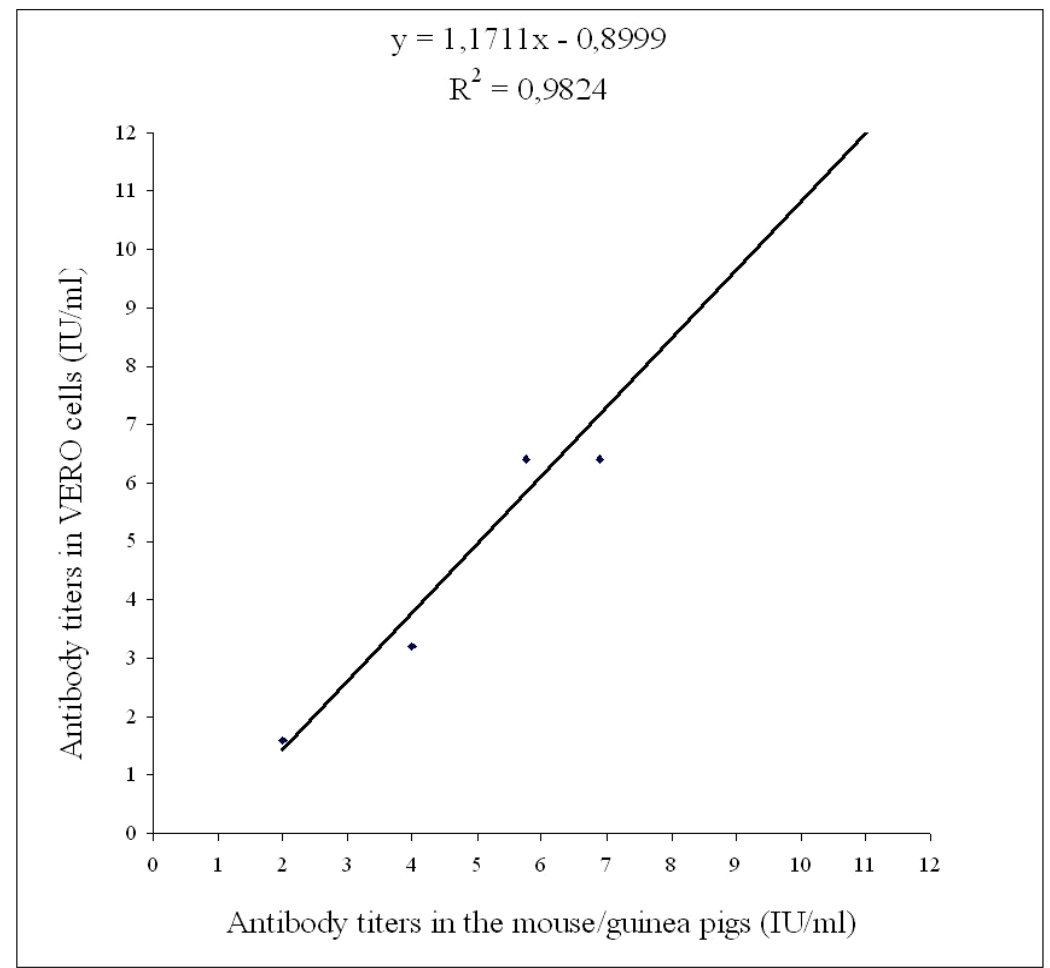

Figure 2. Pearson's correlation between titers of neutralizing antibodies against Clostridium septicum alpha toxin in rabbit sera obtained by seroneutralization in mouse/guinea pig and in VERO cells culture, $\mathrm{R}^{2}=0.9824$. 
Results obtained with the seroneutralization demonstrate that the standardized test can be used to evaluate the efficiency of vaccines against $C$. septicum. Only five out of nine vaccines tested obtained antibody titers higher than the legal minimal threshold of $2.5 \mathrm{IU} / \mathrm{mL}$, as required by the Brazilian law (Brasil, 1997). These data agree with conclusions reported by Lobato et al. (2008) in a study evaluating 12 vaccines against $C$. septicum in the Brazilian market, which found that only five induced protective titers. Thus, most currently available vaccines are inefficient and there is the need for implementation of effective controls of this immunogen.

This study demonstrated that antibodies against C. septicum alpha toxin can be detected in a precise, sensitive, practical, and relatively quick way, with a significant reduction in the number of animals used. In vitro seroneutralization of VERO cells culture, a method standardized in this experiment, was shown to be a viable alternative to the current in vivo model used for clostridial vaccine potency test with $C$. septicum alpha toxoid.

\section{ACKNOWLEDGMENTS}

The authors are grateful to Dr. Ângela Quintão e Dr. Marcos Xavier who carried out the statistical analyses and CNPq, FAPEMIG, and FEPMVZ for financial support.

\section{REFERENCES}

ASSSIS, R.A.; LOBATO, F.C.F.; NASCIMENTO, R.A.P. et al. Mionecroses clostridiais bovinas. Arq. Inst. Biol., v.77, p.331-334, 2010.

ASSIS, R.A.; LOBATO, F.C.F.; LOBATO, Z.I.P. et al. PCR multiplex para identificação de isolados de Clostridium chauvoei e Clostridium septicum. Arq. Bras. Med. Zootec., v.60, p.294-298, 2008.

BALLARD, J.; BRYANT, A.; STEVENS, D. et al. Purification and characterization of the lethal toxin (alpha-toxin) of Clostridium septicum. Infect. Immun., v.60, p.784-790, 1992.

BALDASSI, L.; HIPÓLITO, M.; CALIL, E.M.B. Observações sobre a incidência da gangrena gasosa e carbúnculo sintomático durante 10 anos no estado de São Paulo. Biológico, v.51, p.161-165, 1985.
BRASIL. Ministério da Agricultura, Pecuária e Abastecimento. Portaria n. 49 de 12 de maio de 1997. Diário Oficial da União, Brasília, 16 de maio de 1997. Seção 1, p.10168-10169.

BRITISH PHARMACOPEIA. Veterinary Antisera and Veterinary Vaccines. 3.ed. Sainte Ruffine: Maisonneuve S.A. 1998, 192p.

HANG'OMBE, M.B.; MUKAMOTO, M.; KOHDA, T. et al. Cytotoxicity of Clostridium septicum alphatoxin: its oligomerization in detergent resistant membranes of mammalian cells. Microb. Pathog., v.37, p.279-286, 2004.

KNIGHT, P.A.; TILLERAY, J.H.; QUEMINET, J. In vitro test for the measurement of veterinary Clostridial toxins, toxoids and antisera. I. Titration of Clostridium septicum toxins and antitoxins in cell culture. Biologicals, v.18, p.181-189, 1990a.

KNIGHT, P.A.; QUEMINET, J.; BLANCHARD, J.H. et al. In vitro tests for the measurement of clostridial toxins, toxoids and antisera. II. Titration of Clostridium perfringens toxins and antitoxins in cell culture. Biologicals, v.18, p.263-270, 1990 b.

LOBATO, F.C.F., DIAS, L.D., SALVARANI, F.M. et al. Avaliação da potência de vacinas contra Clostridium septicum comercializadas no Brasil. Arq. Inst. Biol., v.75, p.225-228, 2008.

POPOFF, M.R.; BOUVET, P. Clostridial toxins. Future Microbiol., v.4, p.1021-1064, 2009.

METZ, B.; HENDRIKSEN, C.F.M.; JISKOOT; W. et. al. Reduction of animal use in human vaccine quality control: opportunities and problems. Vaccine, v.20, p.2411-2430, 2002.

SAKURAI, J; KOBAYASHI, K. Lethal and dermonecrotic activities of Clostridium perfringens iota toxin: biological activities induced by cooperation of two nonlinked components. Microbiol. Immunol., v.39, p.249-253, 1995.

SAMPAIO, I.B.M. Estatística aplicada à experimentação animal. Belo Horizonte: FEPMVZ, 1998. 221p.

SOUZA JÚNIOR, M.F.; LOBATO, Z.I.P.; PIRES, P.S. et al. Padronização da titulação da toxina épsilon de Clostridium perfringens tipo D em linhagem contínua de células como alternativa ao bioensaio animal. Cienc. Rural, v.40, p.600-603, 2010. 